\title{
Bioactive Compound Activity Inducement of Thermophile Cyanobacterium aponinum Under Stress Conditions
}

\section{Stres Koşulları Altında Termofil Cyanobacterium aponinum Biyoaktif Bileşik Aktivitesinin İndüklenmesi}

\author{
Nur Koçberber Kılıç*๑ and Gönül Dönmez \\ Department of Biology, Ankara University, Beşevler, Ankara, Turkey.
}

\section{ABSTRACT}

$\mathrm{n}$ this report, bioactive properties of 7 thermophile cyanobacteria isolated from thermal springs in Turkey were investigated. Of these, Strain $\mathrm{H} 2$ having the highest antimicrobial activity was identified as Cyanobacterium aponium. Bioactive character of cyanobacterial biomass was investigated with regards to different nitrogen concentrations $(0.5 \mathrm{~g} / \mathrm{L}, 1.0 \mathrm{~g} / \mathrm{L}$, $1.5 \mathrm{~g} / \mathrm{L}$, and $2.0 \mathrm{~g} / \mathrm{L}$ ), light intensities (1200lx, $2400 \mathrm{~lx}, 3600 \mathrm{~lx}$, and $4800 \mathrm{~lx}$ ), incubation periods (7 d, $14 \mathrm{~d}, 21 \mathrm{~d}$, and $28 \mathrm{~d}$ ), and temperatures $\left(30^{\circ} \mathrm{C}, 40^{\circ} \mathrm{C}, 45^{\circ} \mathrm{C}\right.$, and $\left.50^{\circ} \mathrm{C}\right)$. It was observed that the effectiveness of bioactive substances produced by cyanobacteria was induced by stress conditions. When $C$. aponinum was exposed to high light intensity or temperature, cyanobacteria produced more efficient bioactive compounds then other environmental conditions tested. The highest antimicrobial activity was found against E. coli 0157:H7 ATCC 35150 with biomass extracts obtained when cyanobacterium cultivated in media with $1.0 \mathrm{~g} / \mathrm{L}$ nitrogen, at $45^{\circ} \mathrm{C}$, under $3600 \mathrm{~lx}$ illumination after incubation for 14 days. For the first time with such an approach as in the current study, production of bioactive compounds by a thermophilic $C$. aponinum and optimization of the environmental conditions to obtain the most efficient biologically active compounds was investigated.

\section{Key Words}

Bioactive compounds; Cyanobacterium aponinum; thermophile; stress.

\section{öz}

B u çalışmada, Türkiye'de kaplıcalardan izole edilen 7 termofil siyanobakterinin biyoaktif özellikleri araştırılmıştır. Bunlardan en yüksek antimikrobiyel aktiviteye sahip olan Suş $\mathrm{H} 2$, Cyanobacterium aponium olarak tanılanmıştır. Siyanobakteriyel biyokütlenin biyoaktif karakteri, farklı azot konsantrasyonları $(0.5 \mathrm{~g} / \mathrm{L}, 1.0 \mathrm{~g} / \mathrm{L}, 1.5 \mathrm{~g} / \mathrm{L}$ ve $2.0 \mathrm{~g} / \mathrm{L})$, ışık yoğunlukları (1200lx, 2400 Ix, 3600 lx ve 4800 lx), inkübasyon süreleri (7 gün, 14 gün, 21 gün ve 28 gün) ve sıcaklıklar $\left(30^{\circ} \mathrm{C}, 40^{\circ} \mathrm{C}, 45^{\circ} \mathrm{C}\right.$ ve $50^{\circ} \mathrm{C}$ ) açııından araştırılmıştır. Siyanobakteriler tarafından üretilen biyoaktif maddelerin etkinliğinin stres koşulları tarafından tetiklendiği gözlenmiştir. C. aponinum yüksek ışık yoğunluğuna veya sıcaklığa maruz kaldığında, siyanobakteriler test edilen diğer çevresel koşullardan daha verimli biyoaktif bileşikler üretmiştir. En yüksek antimikrobiyel aktivite, siyanobakteri $1.0 \mathrm{~g} / \mathrm{L}$ azot içeren bir ortamda, $3600 \mathrm{Ix}$ ışı şiddeti altında, $45^{\circ} \mathrm{C}^{\prime}$ de 14 gün boyunca inkübasyondan sonra elde edilen biyokütleden alınan ekstraktlar ile E. coli 0157: H7 ATCC 35150’ye karşı bulunmuştur. Bu çalışmada ilk kez böyle bir yaklaşımla, termofilik $C$. aponinum tarafından biyoaktif bileşiklerin üretilmesi ve en etkin biyoaktif bileşikleri elde etmek için çevresel koşulların optimizasyonu araştırılmıştır.

\section{Anahtar Kelimeler}

Biyoaktif bileşikler; Cyanobacterium aponinum; termofil; stres. 


\section{INTRODUCTION}

Cyanobacteria and microalgae are rich source of unique and biologically active products known as bioactive compounds [1]. Among the microorganisms with potential for producing bioactive compounds, cyanobacteria appear as ideal candidates forming novel biologically active compounds [2]. They require only minimal nutrition using sunlight, carry out nitrogen and $\mathrm{CO}_{2}$ fixation and grow fast by utilizing different carbon sources.

Several cyanobacteria can produce bioactive compounds with different biological activities like antibacterial, antifungal, anticancer and antiviral. Among cyanobacteria, extremophile ones coping with extreme conditions (high salt concentration, temperatures, etc.) have much greater potential in various biotechnological applications such as energy and production of useful substances. Such microorganisms maintain their vitality by producing more stable materials in adapting to changing environmental conditions [3-5]. Moreover, thermophilic cyanobacteria can produce biomass more quickly than mesophilic cyanobacteria by fixing $\mathrm{CO}_{2}$ in the carbon cycle [6]. Properties like survival in different environments, rapid growth and plenty of biomass formation are required for effective biotechnological applications.

Previous studies were mostly focused on mesophilic cyanobacteria having bioactive character. But, however, research on thermophilic cyanobacteria are very limited [1]. Fish and Codd reported that thermotolerant Phormidium species produced extracellular antimicrobial materials inhibiting growth of Gram-positive and Gram-negative bacteria, Candida albicans, and Cladosporium resinae, while not cyanobacteria [7]. Heidari et al. used Oscillatoria subbrevis, O. tenius, O. limentica, O. angusta, O. articulate, Synechocystis aquatilis, and Synechoccous cerdrorum that were isolated from Geno hot springs; the highest antimicrobial activity was found against Bacillus subtilis and $B$. pumulis with methanol-extracts of these thermophile cyanobacteria [8]. A thermophilic green algae Cosmarium $\mathrm{sp}$. isolated from hot spring in north Tunisia was tested for its bioactive properties; extracts prepared by using different solvents showed significant antibacterial effects [9]. A recent report that was carried out with thermophile $C$. aponinum isolated from Polichnitos hot spring showed that extracts from $C$. aponinum had no antimicrobial activity against bacteria even the extracts were used at high dosage. In the same study, extracts of the cyanobacterium had significant insecticidal activity against $A$. aegypti larvae and anticancer activity against cancer cell line PC3 [10]. In the current study, a thermophile $C$. aponinum isolated from hot springs in Turkey was investigated for its bioactive compound production. For this purpose, different nitrogen concentrations, light intensities, incubation periods, and temperatures were tested to determine the most effective bioactive compound produced by $C$. aponinum. Our main goal was to investigate the optimal conditions for a highly efficient bioactive compound production by the tested cyanobacterium that could be used in various biotechnological applications like pharmaceutical industry. It is known that to work with an organism that can cope with extreme conditions is advantageous according to its more stable compounds production [11]. In addition, it has been known that extremophiles can resist microbial contaminations by growing well under hard environmental conditions like temperature, extreme $\mathrm{pH}$, and high salt concentrations. Therefore, a thermophile cyanobacterium was used to obtain bioactive compounds, tested its possible antimicrobial activity, and conditions were optimized for the highest bioactive property in the current study. According to our knowledge, there is no work about investigating thermophile $C$. aponinum for biotechnological applications like in this work.

\section{MATERIALS and METHODS}

\section{Cyanobacteria isolation, growth conditions}

Thermal spring water samples from Haymana and Kızılcahamam, Turkey, were spread on Petri plates containing BG11 medium [12] with $12 \mathrm{~g} / \mathrm{L}$ agar and incubated at $45^{\circ} \mathrm{C}$ under continuous illumination (2400 lux). The $\mathrm{pH}$ of the growth medium was adjusted to 7.5 with dilute $(0.01$ $\mathrm{M})$ and concentrated (1 M) sulfuric acid or sodium hydroxide solutions. Cells from microcolonies on these plates were isolated by micromanipulation. The cyanobacterial cells were purified to aseptic conditions by streaking the cells repeatedly on the media with agar plate. The purified cells were transferred to liquid media. These liquid cultures were tested for bacterial contamination by plating on bacteriological media. Isolated and purified cyanobacterial cultures were identified according to morphological and genetic characteristic.

Cyanobacterial strains were cultivated in $250 \mathrm{ml}$ Erlenmeyer flasks including $100 \mathrm{ml}$ of BG11 medium ( $\mathrm{pH}$ : 7.5) at $30^{\circ} \mathrm{C}$, under continuous light intensity as $2400 \mathrm{~lx}$ at a growth chamber (BINDER, model: KBW 400 (E5.1), S.no: 15-13640) for 14 days. 


\section{Selection of Cyanobacteria}

Cyanobacteria used in the study were tested to determine having the most effective bioactive compound. In these experiments, 7 different strains were inoculated in BG11 medium and after incubation period, the effectiveness of bioactive compounds were examined. Cyanobacterium producing the most effective bioactive compound was found and further trials were performed with this cyanobacterium.

\section{Identification}

DNA of the selected cyanobacteria (Strain H2) were amplificated using PCR amplification with $2 \mathrm{ml}$ of genomic DNA, $0.4 \mathrm{mM}$ deoxynucleotide triphosphate, 1.25 units of Taq DNA polymerase and use forward primer F5'AGAGTTTGATCMTGGCTCAG and reverse primer R5' TACGGYTACCTTGTTACGACTT. PCR program was adjusted to $95^{\circ} \mathrm{C}$ for $5 \mathrm{~min}$ followed by 30 cycles of $95^{\circ} \mathrm{C}$ for $30 \mathrm{sec}, 50^{\circ} \mathrm{C}$ for $30 \mathrm{sec}$, and $72^{\circ} \mathrm{C}$ for $45 \mathrm{sec}$. DNA sequencing was performed with Bigdye Cycle sequencing kit v3.1 and ABI 3130XL Genetic Analyzer.

\section{Production of bioactive compounds}

After incubation period of 14 days, biomass was collected by centrifugation (MPW-351R) at $10.000 \mathrm{rpm}$ for 5 min. Biomasses were freeze-dried (Millrock Technology, Inc., Kingston, NY 12401, USA) for overnight and $3 \mathrm{ml}$ ethanol solvent (Purity: 96\%) was added to 1 gram of dried biomass for 1 hour. After then, the mixture was centrifuged for $10.000 \mathrm{rpm}$ for $5 \mathrm{~min}$ and supernatant was used as algal extract. These solutions were kept at $4^{\circ} \mathrm{C}$ and used within 2 days $[13,14]$.

\section{Determination of effectiveness of bioactive compound}

To find the effectiveness of bioactive compound, trials were designated with antimicrobial activity. Antimicrobial activity was determined by disc diffusion method [15]. Standard bacterial strains like B. subtilis ATCC 6633, B. thermosphacta ATCC 11509, E. coli 0157:H7 ATCC 35150, E. coli ATCC 25922, Enterobacter cloacae ATCC 700323, S. aureus ATCC BAA 976, S. aureus ATCC 25923, S. aureus ATCC 1026 were used to perform these experiments. Bacteria were cultivated in Nutrient Broth for 24 $h$, and were inoculated uniformly using sterile cotton swab onto Nutrient Agar to test the antibacterial activities of cyanobacterial extracts. Extracts were applied to sterile disks ( $40 \mu \mathrm{l} /$ per disk) and impregnated disks were placed on the plates using sterile forceps properly spaced at equal distance. Plates were incubated $24 \mathrm{~h}$ for $30^{\circ} \mathrm{C}$. Paper discs loaded with ethanol solvent were also checked for its effect against the standard bacterial strains. The plates were stored for $2 \mathrm{~h}$ to allow of the extracts into the agar. Then, these plates were incubated for $24 \mathrm{~h}$ at $30^{\circ} \mathrm{C}$ for growth of bacteria. The zone of inhibition was measured and expressed in $\mathrm{mm}$ in diameter.

\section{Chlorophyll analysis}

The chlorophyll (a) concentration in the media was determined in buffered aqueous $80 \%$ acetone solution. The concentration of chlorophyll was found with recording optical absorption at 646.6 and $663.6 \mathrm{~nm}$ by using Shimadzu UV 2001 model spectrophotometer (Japan) according to the equation given as below [16].

Chlorophyll (a) $(\mu \mathrm{g} / \mathrm{ml})=\left(12.25 \times \mathrm{A}_{663.6}\right)+\left(2.55 \times \mathrm{A}_{646.6}\right)$

\section{Bioactive compound production under different environmental conditions}

Production of bioactive compounds by the selected cyanobacterium under different environmental conditions was investigated with regard to increasing nitrogen concentrations, light intensities, incubation periods, and temperatures. Unless other stated, cyanobacteria were cultivated in $\mathrm{BG} 11$ medium at $30^{\circ} \mathrm{C}$, under continuous light intensity as $2400 \mathrm{~lx}$ at a growth chamber for 14 days.

To understand the effect of nitrogen concentration on production of bioactive compounds, experiments were performed in media with nitrogen concentrations as $0.5 \mathrm{~g} / \mathrm{L}, 1.0 \mathrm{~g} / \mathrm{L}, 1.5 \mathrm{~g} / \mathrm{L}$, and $2.0 \mathrm{~g} / \mathrm{L}$. Further trials were done with the condition that $C$. aponinum extracts had the highest antimicrobial activities.

Trials were carried out under different light intensities as $1200 \mathrm{Ix}, 2400 \mathrm{Ix}, 3600 \mathrm{~lx}$, and $4800 \mathrm{~lx}$ to find the effect of light intensity on bioactive compound production by $C$. aponinum. Subsequent studies have been carried out with the condition in which the cyanobacterium produced the most efficient bioactive substance.

After optimization of nitrogen concentration and illumination for the highest antimicrobial activities of the extracts, the effect of incubation period was investigated. To determine the most effective bioactive compound produced by $C$. aponinum under different incubation periods, experiments were done with incubation periods as $7,14,21$, and 28 days. Next experiments were 
Table 1. Antimicrobial activity [zone of inhibition $(\mathrm{mm})$ ] of bioactive compounds extracted from cyanobacterial species isolated from Haymana and Kızılcahamam thermal springs $\left(\mathrm{T}: 45^{\circ} \mathrm{C}\right.$; N concentration: $1 \mathrm{~g} / \mathrm{L}$; light intensity: 2400 Ix; incubation period: $14 \mathrm{~d}$ ).

\begin{tabular}{|c|c|c|c|c|c|c|c|}
\hline \multirow{2}{*}{ Bacteria } & \multicolumn{7}{|c|}{ Strain } \\
\hline & H1 & $\mathrm{H} 2$ & H3 & $\mathrm{H} 4$ & H5 & К1 & K2 \\
\hline B. subtilis ATCC 6633 & $9 \pm 1$ & $12 \pm 2$ & $10 \pm 1$ & $12 \pm 1$ & $11 \pm 2$ & $12 \pm 1$ & $8 \pm 1$ \\
\hline B. thermosphacta ATCC 11509 & $10 \pm 2$ & $12 \pm 1$ & $11 \pm 1$ & $11.5 \pm 1$ & $11 \pm 2$ & $11.5 \pm 1$ & $10 \pm 1$ \\
\hline E.coli 0157:H7 ATCC 35150 & $11.5 \pm 1$ & $13 \pm 1$ & $12 \pm 1$ & $13 \pm 1$ & $11.5 \pm 1$ & $13 \pm 1$ & $11 \pm 1$ \\
\hline E. coli ATCC 25922 & $8 \pm 1$ & $14.5 \pm 1$ & $12 \pm 1$ & $12 \pm 1$ & $12 \pm 2$ & $13 \pm 1$ & $10 \pm 1$ \\
\hline E. cloacae 700323 & $8.5 \pm 1$ & $11 \pm 1$ & $11 \pm 1$ & $12 \pm 2$ & $11.5 \pm 2$ & $12 \pm 1$ & $10 \pm 2$ \\
\hline S. aureus ATCC BAA 976 & $9 \pm 2$ & $13 \pm 1$ & $12 \pm 1$ & $12 \pm 1$ & $12 \pm 1$ & $13 \pm 1$ & $10 \pm 1$ \\
\hline S. aureus ATCC 25923 & $7 \pm 1$ & $12 \pm 1$ & $12 \pm 2$ & $12.5 \pm 1$ & $11 \pm 1$ & $12 \pm 2$ & $11 \pm 1$ \\
\hline S. aureus ATCC 1026 & $8 \pm 2$ & $11 \pm 1$ & $10 \pm 2$ & $11 \pm 1$ & $10.5 \pm 1$ & $11 \pm 1$ & $7 \pm 1$ \\
\hline
\end{tabular}

done with the incubation period due to the maximum antimicrobial activities of the samples. Effect of increasing temperature on bioactive compound production by the tested cyanobacterium were performed in another series of the experiments. To examine the effect of different temperatures, trials were performed with incubation temperatures as $30^{\circ} \mathrm{C}, 40^{\circ} \mathrm{C}, 45^{\circ} \mathrm{C}$, and $50^{\circ} \mathrm{C}$.

\section{RESULTS and DISCUSSION}

\section{Selection of cyanobacterium producing the most effec-} tive bioactive compound and its identification

In these trials, 7 different cyanobacterial strains (Strain $\mathrm{H} 1$, Strain H2, Strain H3, Strain H4, Strain H5, Strain K1, and Strain K2) were used. The results obtained from these series of the experiments were summarized in Table 1. All cyanobacterial isolates had antimicrobial activity against all the tested standard bacterial strains. Ethanol-extracts of $\mathrm{H} 1$ affected E. coli 0157:H7 ATCC 35150 bacterium the most with an antimicrobial activity having $11.5 \mathrm{~mm}$ inhibition zone.

On the other hand, extracts from strain $\mathrm{H} 2$ had the highest bioactive properties against E. coli ATCC 25922 with an inhibition zone as $14.5 \mathrm{~mm}$. Cyanobacterial strain $\mathrm{H} 3$ extracts had the maximum antimicrobial activity against four of the tested bacteria as E. coli 0157:H7 ATCC 35150, E. coli ATCC 25922, S. aureus ATCC BAA 976, and S. aureus ATCC 25923 (inhibition zones: $12 \mathrm{~mm}$ ). Extracts from strain H4 affected E. coli 0157:H7 ATCC 35150 with the highest inhibition zone as $13 \mathrm{~mm}$. Strain
H5 had effective bioactive character against E. coli ATCC 25922 and S. aureus ATCC BAA 976 (inhibition zones: 12 $\mathrm{mm})$; while strain $\mathrm{K} 1$ had the highest antimicrobial activity against E. coli 0157:H7 ATCC 35150, E.coli ATCC 25922, and S. aureus ATCC BAA 976 (inhibition zones: 13 $\mathrm{mm})$. Among the cyanobacterial strains, strain $\mathrm{K} 2$ had the highest antimicrobial activity against E. coli 0157:H7 ATCC 35150 and S. aureus ATCC 25923 with inhibition zones as $11 \mathrm{~mm}$. According to data obtained from these trials, further experiments were performed with Strain $\mathrm{H} 2$ related to its highest antimicrobial activity against the all tested bacteria.

The selected cyanobacterium (Strain $\mathrm{H} 2$ ) was identified by amplification and sequencing of its 16S rRNA gene. Phylogenetic analysis of the nearly complete sequence data was done by BLAST search. Alignment and further analysis in ARB database revealed that the cyanobacterium had a $>99 \%$ similarity to Cyanobacterium aponinum. The isolated cyanobacteria submitted to NCBI Gen-Bank under accession number as MN 116003.

There are only a few reports performing antimicrobial activity with extracts from thermophilic cyanobacteria [7-10]. Of the studies except one of them, thermophile $C$. aponinum was not used, while other thermophilic cyanobacteria as Cosmarium sp. [9], Phormidium sp. [7], Oscillatoria spp., Synechocystis aquatilis, and Synechoccous cerdrorum were used to obtain bioactive compounds. In these studies, authors found variable antimicrobial activities according to the cyanobacteria tested. 


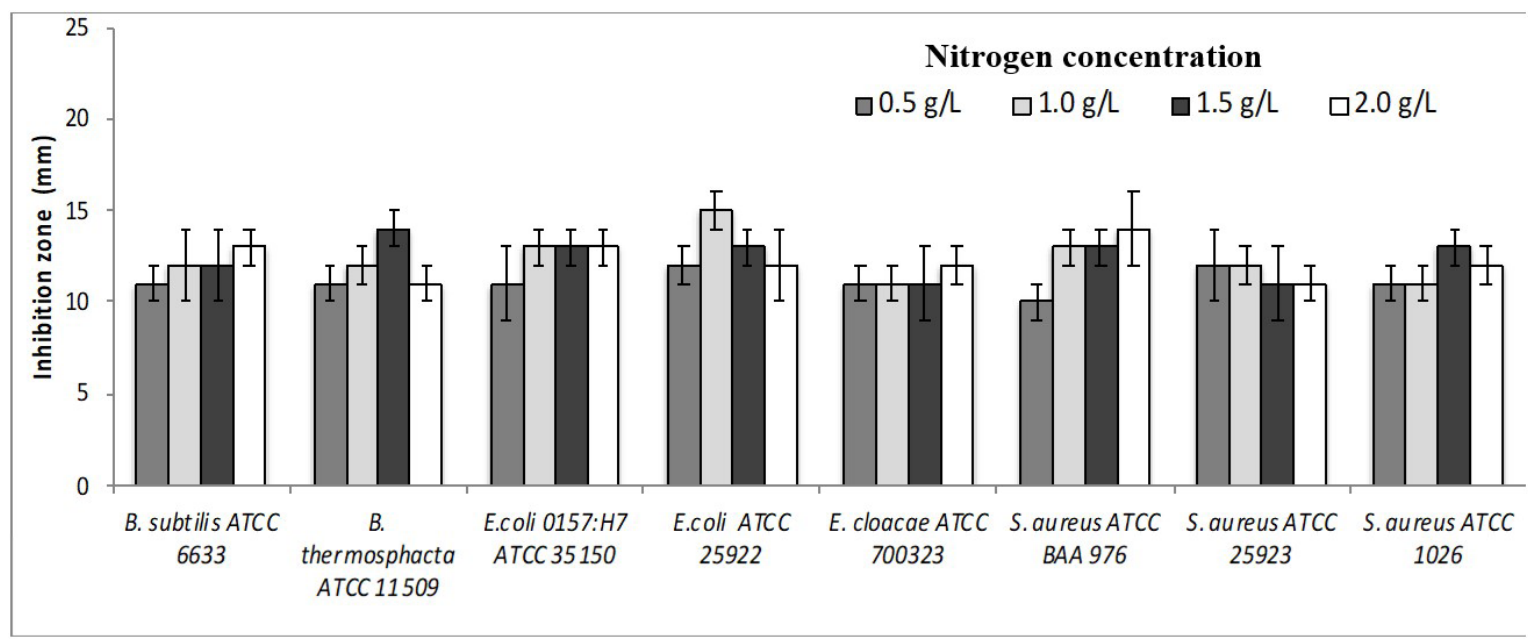

Figure 1. Antimicrobial activities [zone of inhibition $(\mathrm{mm})$ ] of bioactive compounds extracted from C. aponinum under different nitrogen concentrations ( $\mathrm{T}: 30^{\circ} \mathrm{C}$; light intensity: $2400 \mathrm{~lx}$; incubation period: $14 \mathrm{~d}$ ).

The only work mentioned about thermophilic $C$. aponinum was performed by Mizerakis et al. [10]. In that study, there was no antimicrobial activity against bacteria, however, in the current study, ethanol-extracts of thermophilic $C$. aponinum showed high antimicrobial activity against several bacterial strains.

\section{Bioactive compound production by $C$. aponinum cultivated in media with different environmental conditions}

\section{The effect of different nitrogen concentrations}

To determinate the effect of different nitrogen concentrations onto production of bioactive compounds by $C$. aponinum, cyanobacterium was inoculated in to BG 11 media with $0.5 \mathrm{~g} / \mathrm{L}, 1.0 \mathrm{~g} / \mathrm{L}, 1.5 \mathrm{~g} / \mathrm{L}$, and $2.0 \mathrm{~g} / \mathrm{L}$ nitrogen concentration. As it was shown in Figure 1 , extracts from cyanobacterium grown in media with $0.5 \mathrm{~g} / \mathrm{L}$ nitrogen, the highest antimicrobial activity was shown against E. coli ATCC 25922 and S. aureus ATCC 25923 with inhibition zones as $12 \mathrm{~mm}$. Extracts obtained from C. aponinum, grown in media with $1.0 \mathrm{~g} / \mathrm{L}$ nitrogen, the highest antimicrobial activity was shown against $E$. coli ATCC 25922 (inhibition zone: $15 \mathrm{~mm}$ ). When the cyanobacterium was grown in medium containing $1.5 \mathrm{~g} / \mathrm{L}$ of nitrogen, the extract prepared from that biomass showed the highest antimicrobial effect, producing $14 \mathrm{~mm}$ inhibition zone against B. thermosphacta ATCC 11509. The highest bioactive property was shown against $S$. aureus ATCC BAA 976 (inhibition zone: $14 \mathrm{~mm}$ ) with the extracts obtained from biomasses from which $C$. aponi- num cultivated in media with $2.0 \mathrm{~g} / \mathrm{L}$ nitrogen concentration. According to these results, further experiments were done in media with $1.0 \mathrm{~g} / \mathrm{L}$ nitrogen related to extracts having the highest bioactive property.

In these experiments, with an increase in nitrogen concentration, antimicrobial effect also increased or remained constant for the tested bacteria. Previous studies only focused on to determine growth, fatty acid production and accumulation due to the nitrogen stress in $C$. aponinum [17-19]. Such an attempt like in the current study has not been investigated yet.

Chlorophyll amounts were also determined under all the tested parameters. Chlorophyll contents of the C. aponinum were $2.2 \mu \mathrm{g} / \mathrm{ml}, 5.2 \mu \mathrm{g} / \mathrm{ml}, 2.6 \mu \mathrm{g} / \mathrm{ml}$, and 2.4 when cyanobacteria were cultivated in media under $0.5 \mathrm{~g} / \mathrm{L}, 1.0$ $\mathrm{g} / \mathrm{L}, 1.5 \mathrm{~g} / \mathrm{L}$, and $2.0 \mathrm{~g} / \mathrm{L}$ nitrogen concentrations, respectively.

\section{The effect of different light intensities}

In these series of the experiments the increment in light intensities varied the antimicrobial character of the bioactive compounds. Figure 2 summarized that with an increase in light intensities, antimicrobial activity of the extracts increased also. When $C$. aponinum cultivated at $1200 \mathrm{Ix}$ light intensity, extracts obtained under these conditions showed the highest antimicrobial activity against E. coli 0157:H7 ATCC 35150 and S. aureus ATCC BAA 976 (inhibition zones: $14 \mathrm{~mm}$ ). Under the same conditions, the lowest antimicrobial activity was found 


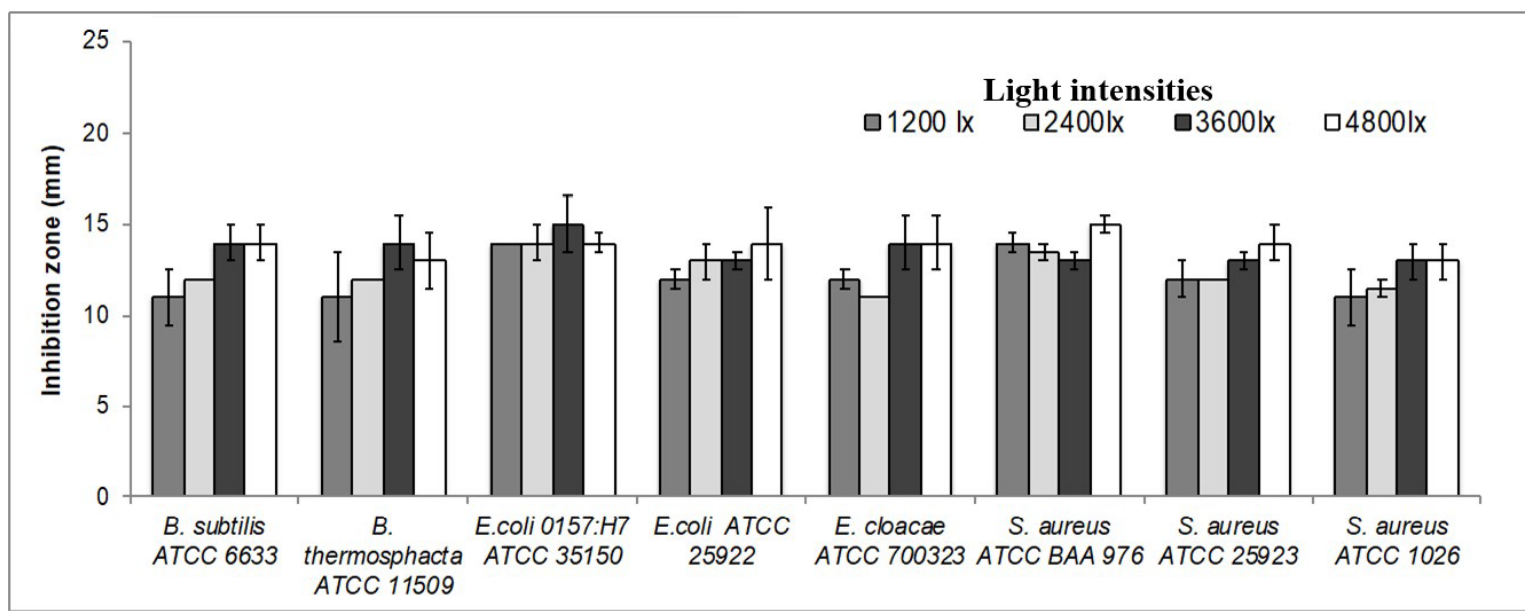

Figure 2. Antimicrobial activities [zone of inhibition $(\mathrm{mm})$ ] of bioactive compounds extracted from $C$. aponinum under different light intensities ( $\mathrm{T}: 30^{\circ} \mathrm{C} ; \mathrm{N}$ concentration: $1 \mathrm{~g} / \mathrm{L}$; incubation period: $14 \mathrm{~d}$ ).

against B. subtilis ATCC 6633, B. thermosphacta ATCC 11509 and S. aureus ATCC 1026 bacteria with inhibition zones as $11 \mathrm{~mm}$. When cyanobacterium was cultivated at 2400 Ix light intensity, the highest antimicrobial activity was shown against E. coli 0157:H7 ATCC 35150 with an inhibition zone as $14 \mathrm{~mm}$, while the lowest inhibition zone was $11 \mathrm{~mm}$ against E. cloacae ATCC 700323. With bioactive compounds obtained from $C$. aponinum grown at light intensity as $3600 \mathrm{~lx}$, the highest antimicrobial activity was found as $15 \mathrm{~mm}$ against $E$. coli 0157:H7 ATCC 35150. Under the same light intensity, bioactive compounds showed high antimicrobial activity against the all bacteria tested with inhibition zones ranged from 13 or $14 \mathrm{~mm}$. When light intensity was increased to $4800 \mathrm{~lx}$, cyanobacterium still produced effective bioactive compounds. Under these conditions, the most effective compound was found against $S$. aureus ATCC BAA 976 (inhibition zone: $15 \mathrm{~mm}$ ), while antimicrobial activities for other bacteria varied from 13 or 14 $\mathrm{mm}$. At the end of these experiments, further experiments were done under 3600 Ix light intensity.

Gris et al. showed that thermophilic C. aponinum produced extracellular compounds under different environmental conditions [20]. In that study, the formation of extracellular polymer by $C$. aponinum was induced with an increase in light intensity and it was constant above the light intensity as $70 \mu \mathrm{mol}$ photons $\mathrm{m}^{2} / \mathrm{s}$. Another previous study about thermophile $C$. aponinum mentioned the effect of stress conditions as temperature, $\mathrm{pH}, \mathrm{CO}_{2}$ and light quality on $\mathrm{C}$. aponinum growth [21]. In the same study, cyanobacterium was exposed to four light qualities; of these, under white light with $60 \mu \mathrm{mol}$ photons $\mathrm{m}^{2} / \mathrm{s}$ intensity, C. aponinum achieved a high growth rate. In the current study, when the increment of the illumination from $16 \mu \mathrm{mol}$ photons $\mathrm{m}^{2} / \mathrm{s}$ to 32,48 , or $64 \mu \mathrm{mol}$ photons $\mathrm{m}^{2} / \mathrm{s}, \mathrm{C}$. aponinum produced more efficient bioactive compounds.

According to the results, with an increase in light intensity, chlorophyll amount was also increased by the cyanobacterium. Under $1200 \mathrm{~lx}$, chlorophyll content was $3.1 \mu \mathrm{g} / \mathrm{ml}$; while it was $4.4 \mu \mathrm{g} / \mathrm{ml}$ under $2400 \mathrm{~lx}$. When light intensity was increased to $3600 \mathrm{~lx}$ and $4800 \mathrm{~lx}$, chlorophyll amounts were found as $6.1 \mu \mathrm{g} / \mathrm{ml}, 4.8 \mu \mathrm{g} /$ $\mathrm{ml}$, respectively.

\section{The effect of different incubation periods}

Antimicrobial activities of bioactive compounds extracted from C. aponinum cultivated with different incubation periods were given in Figure 3. When cyanobacterium was grown with an incubation period as 7 days, obtained extracts showed lower antimicrobial activity than extracts taken from biomasses cultivated other incubation periods. Extracts obtained from biomasses after incubation for 7 days showed the highest bioactive properties against E. coli 0157:H7 ATCC 35150 and E. cloacae ATCC 700323 (inhibition zones: 12 mm). It was found that the most effective bioactive compound was produced after incubation for 14 days. Under these incubation period, E. coli 0157:H7 ATCC 35150 was affected the most by the extracts of $C$. aponinum with an incubation zone as $17.5 \mathrm{~mm}$. After incubation for 21 days, bioactive compounds obtained from cyanobacterium 


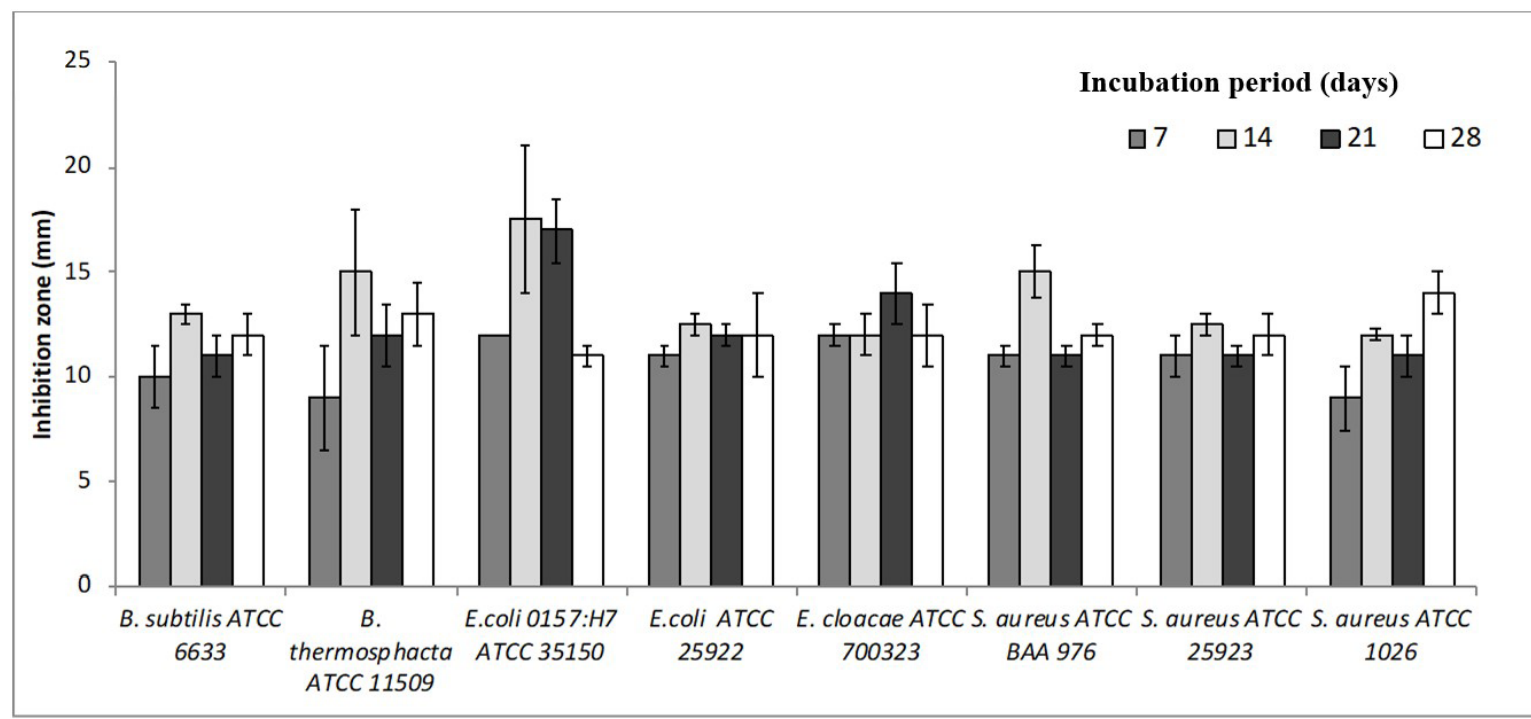

Figure 3. Antimicrobial activities [zone of inhibition $(\mathrm{mm})$ ] of bioactive compounds extracted from $\mathrm{C}$. aponinum under incubation periods ( $\mathrm{T}: 30^{\circ} \mathrm{C}$; $\mathrm{N}$ concentration: $1 \mathrm{~g} / \mathrm{L}$; light intensity: $3600 \mathrm{~lx}$ ).

had the maximum antimicrobial activity against $E$. coli 0157:H7 ATCC 35150 (incubation zone: $17 \mathrm{~mm}$ ). Trials in which the tested cyanobacterium was cultivated for 28 days, extracts had their highest antimicrobial activity towards S. aureus ATCC 1026 (inhibition zone: 14 mm).

Incubation period is a substantial factor for cyanobacterial bioactive compound formation. These unique biologically active compounds can be produced via primary metabolism, like proteins, fatty acids, vitamins, and pigments, or can be formed from secondary metabolism [22]. It was previously determined by Noaman et al. that Synecoccus leopoliensis showed the maximum antimicrobial properties with extracts obtained when cyanobacteria were cultivated with an incubation period for 14 or 15 days [23]. In the current study, it was also found that $C$. aponinum had the most efficient bioactive compound when the incubation period was 14 days.

The highest chlorophyll amount was determined after incubation for 14 and 21 days $(6.2 \mu \mathrm{g} / \mathrm{ml})$. Chlorophyll content of the cyanobacterium was $1.9 \mu \mathrm{g} / \mathrm{ml}$ and 5.1 $\mu \mathrm{g} / \mathrm{ml}$ when $C$. aponinum was cultivated in media under different incubation periods as $7 \mathrm{~d}$ and $28 \mathrm{~d}$, respectively. The most effective compounds were produced after incubation for 14 days. Thus, incubation period was optimized as $14 \mathrm{~d}$.

\section{The effect of temperatures}

To understand the effect of increasing temperatures onto production of bioactive compounds, cyanobacterium was cultivated at $30^{\circ} \mathrm{C}, 40^{\circ} \mathrm{C}, 45^{\circ} \mathrm{C}$ and $50^{\circ} \mathrm{C}$. As it was shown in Figure 4, extracts from cyanobacterium grown at $30^{\circ} \mathrm{C}$, the highest antimicrobial activity was shown against $B$. thermosphacta ATCC 11509 with an inhibition zone as $13 \mathrm{~mm}$. Extracts obtained from C. aponinum grown in media at $40^{\circ} \mathrm{C}$, the highest antimicrobial activity was shown against $B$. subtilis ATCC 6633 and S. aureus ATCC 1026 (inhibition zones: $13 \mathrm{~mm}$ ). When the cyanobacterium was grown in medium at $45^{\circ} \mathrm{C}$, the extract prepared from that biomass showed the highest antimicrobial effect, producing $18 \mathrm{~mm}$ inhibition zone against E. coli 0157:H7 ATCC 35150. The highest bioactive property was shown against E. coli ATCC 25922 (inhibition zone: $14 \mathrm{~mm}$ ) with the extracts obtained from biomasses from which $\mathrm{C}$. aponinum cultivated at $50{ }^{\circ} \mathrm{C}$. In these experiments, it was determined that the bioactive effectiveness of the extracts increased which were obtained from the biomass when the temperature was increased from $30^{\circ} \mathrm{C}$ to $45^{\circ} \mathrm{C}$. Increasing the temperature by more than $45^{\circ} \mathrm{C}$ caused a decrease of cyanobacterial growth, and later the cells dead. This result was easily visible because of color change of the cells from blue-green to brown. 


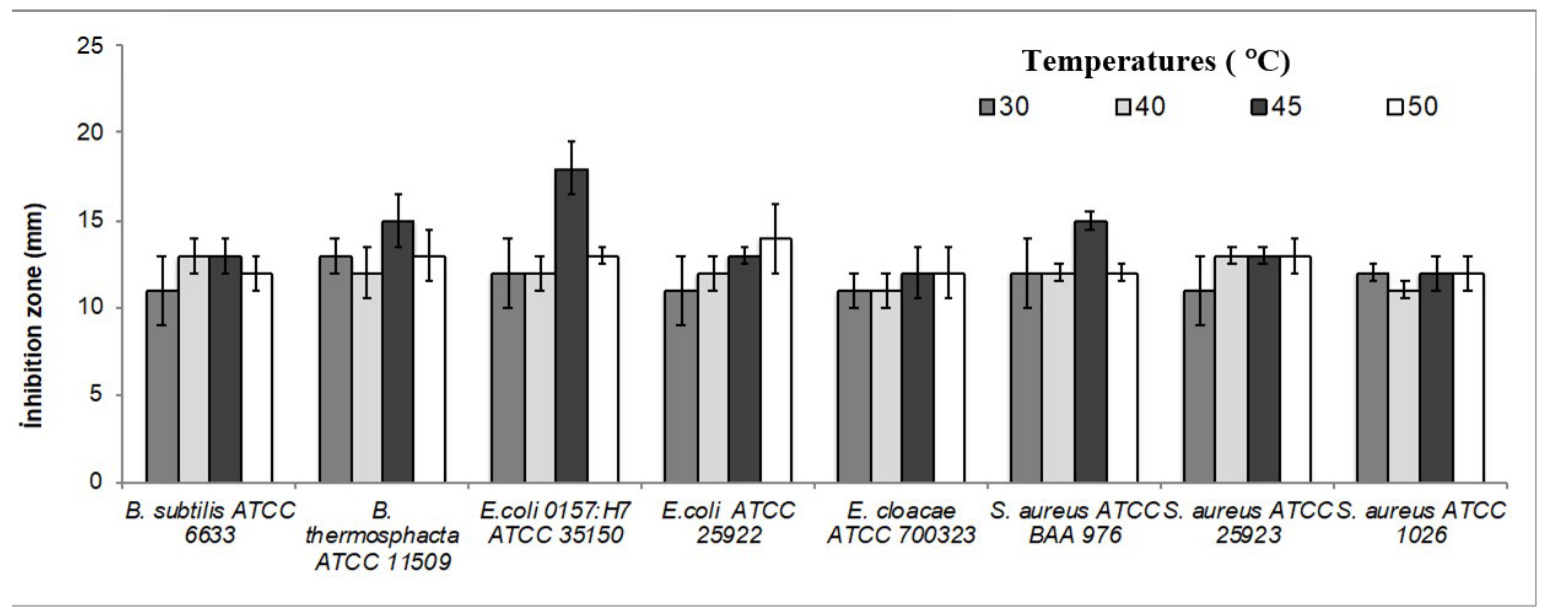

Figure 4. Antimicrobial activities [zone of inhibition $(\mathrm{mm})$ ] of bioactive compounds extracted from $\mathrm{C}$. aponinum under different temperatures ( $\mathrm{N}$ concentration: $1 \mathrm{~g} / \mathrm{L}$; light intensity: $3600 \mathrm{~lx}$; incubation period: $14 \mathrm{~d}$ ).

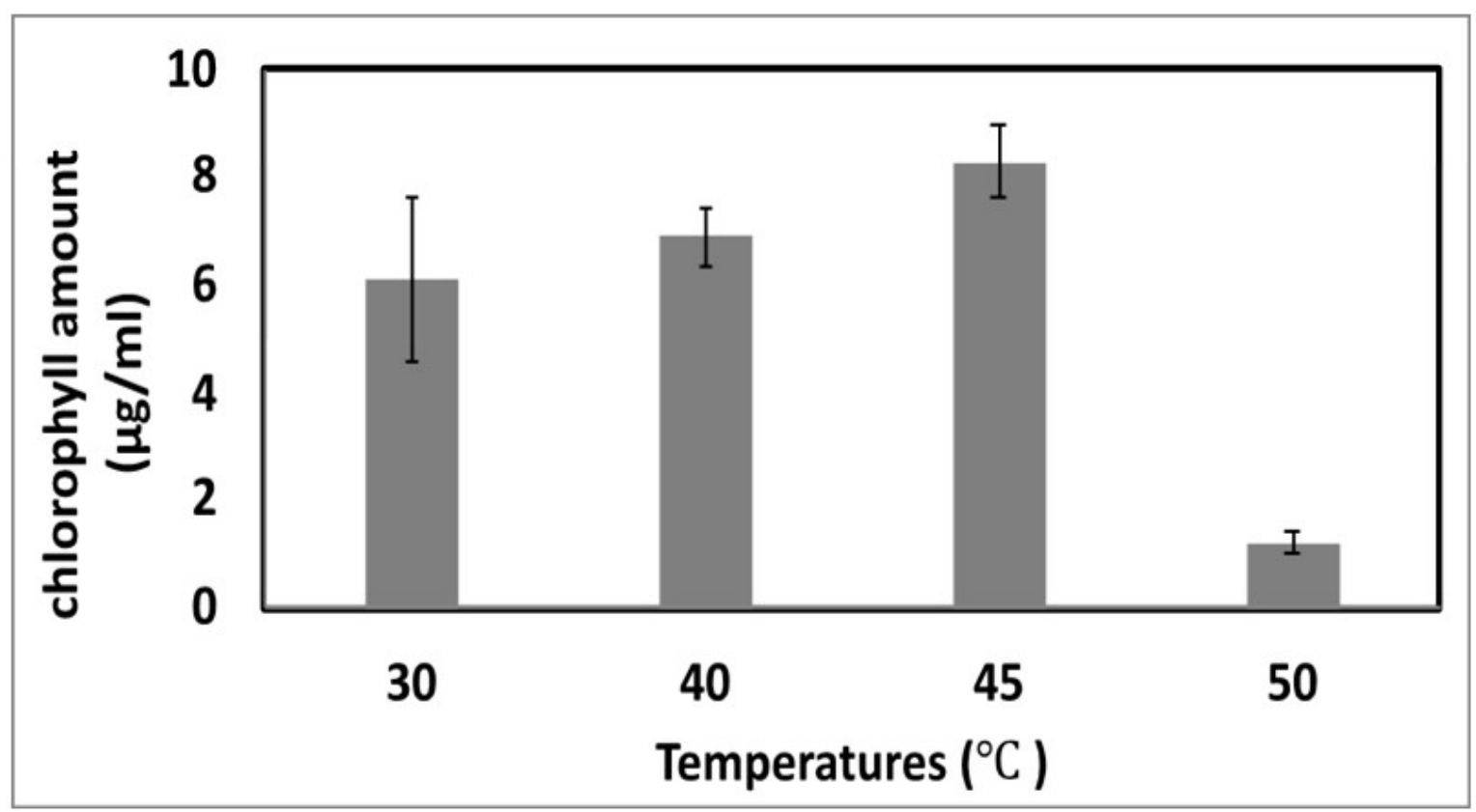

Figure 5. Chlorophyll amounts of $C$. aponinum under different temperatures ( $N$ concentration: $1 \mathrm{~g} / \mathrm{L}$; light intensity: 3600 lx; incubation period: $14 \mathrm{~d}$ ). 
The most effective parameter which affected the cyanobacterium was temperature. It was clearly understood from Figure 5 that the tested cyanobacterium produced the highest amount of chlorophyll under $45^{\circ} \mathrm{C}$ as $8.3 \mathrm{\mu g} / \mathrm{ml}$. Under $30^{\circ} \mathrm{C}$ and $35^{\circ} \mathrm{C}, \mathrm{C}$. aponinum had chlorophyll amounts as $6.1 \mu \mathrm{g} / \mathrm{ml}$ and $6.9 \mu \mathrm{g} / \mathrm{ml}$, respectively, while the content was $1.2 \mu \mathrm{g} / \mathrm{ml}$ when cultivated at $50^{\circ} \mathrm{C}$.

It was previously reported that thermophilic C. aponinum can be survived up to $50^{\circ} \mathrm{C}[20,21]$. Gris et al. found the maximum growth rate at $40^{\circ} \mathrm{C}$, extracellular polymer production at $35^{\circ} \mathrm{C}$ [20], while Meng et al. determined the highest biomass production at $35^{\circ} \mathrm{C}$ [21]. In the current study, the most efficient bioactive compound was observed when cyanobacterium was cultivated under $45^{\circ} \mathrm{C}$. The tested cyanobacterium was affected mostly temperature parameter and antimicrobial activity had its highest rate when temperature was increased.

\section{CONCLUSIONS}

Formation of bioactive compounds by $C$. aPoninum isolated from thermal springs of Turkey was investigated in the current study. The study was concluded that extracts of this thermophilic cyanobacterium had antimicrobial activity against several standard bacterial strains. In addition, it was found that efficiencies of the bioactive compounds could be induced via exposure to stress conditions like high light intensities and temperatures. According to our knowledge, this issue will be firstly presented by the current work. The highest efficiency was found in extracts of $C$. aponinum when the extremophile cyanobacterium was cultivated in media with $1 \mathrm{~g} / \mathrm{L}$ nitrogen, at $45^{\circ} \mathrm{C}$, under $3600 \mathrm{~lx}$ light intensity after incubation for 14 days. These findings obtained from the current study has indicated that thermophile C. aponinum might be a good promising candidate in several biotechnological applications such as designing of new antibacterial drugs.

\section{References}

1. A. Patel, L. Matsakas, U. Rova, P. Christakopoulos, A perspective on biotechnological applications of thermophilic microalgae and cyanobacteria, Biores. Technol., 278 (2019) 424-434.

2. S. Dobretsov, R.M.M. Abed, S.M.S. Al Maskari, J.N. Al Sabahi, R. Victor, Cyanobacterial mats from hot springs produce antimicrobial compounds and quorum-sensing inhibitors under natural conditions, J. Appl. Phycol., 23, (2011) 983993.

3. A. Drobac-Čik, T.I. Dulic, D.B. Stojanovic, Z.B. Svircev, The Importance of extremophile cyanobacteria in the production of biologically active compounds, Matica Srpska J. Nat. Sci., 112, (2007) 57-66.

4. C. Pumas, P. Vacharapiyasophon, Y. Peerapornpisal, P. Leelapornpisid, W. Boonchum, M. Ishii, C. Khanongnuch, Thermostablility of phycobiliproteins and antioxidant activity from four thermotolerant cyanobacteria, Phycol. Res., 59, (2011) 166-174.

5. N. Mezhoud, F. Zili,, N. Bouzidi, F. Helaoui, J. Ammar, H.B. Ouada, The effects of temperature and light intensity on growth, reproduction and eps synthesis of a thermophilic strain related to the genus Grasiella, Bioproc. Biosyst. Eng., 37 (2014) 2271-2280.

6. J-L. Leu, T-H. Lin, M.J.P. Selvamani, H-C. Chen, J-Z. Liang, K-M. Pan, Characterization of a novel thermophilic cyanobacterial strain from taian hot springs in Taiwan for high $\mathrm{CO}_{2}$ mitigation and c-phycocyanin extraction, Process Biochem., 48 (2013) 41-48.

7. S.A. Fish, G.A. Codd, Bioactive compound production by thermophilic and thermotolerant cyanobacteria (bluegreen algae), W. J. Microbiol. Biotechnol., 10 (1994) 338-341.

8. F. Heidari, H. Riahi, M. Yousefzadi, M. Asadi, Antimicrobial activity of cyanobacteria Isolated from hot spring of geno, Middle-East J. Sci. Res., 12 (2012) 336-339.

9. R. Challouf, R. Ben Dhieb, H. Omrane, K. Ghozzi, H. Ben Ouada, Antibacterial, antioxidant and cytotoxic activities of extracts from the thermophilic green alga, Cosmarium sp., Afr. J. Biotechnol., 11 (2012) 14844-14849.

10. P. Mizerakis, P. Stathopoulou, G. Tsiamis, M.N. Baeshen, J.A. Mahyoub, A.M. Elazzazy, S. Bellou, E. Sakoulogeorga, I-E. Triantaphyllidou, T. Mazioti, P. Katsoris, G. Aggelis, Bacterial diversity of the outflows of a polichnitos (lesvos, greece) hot spring, laboratory studies of a Cyanobacterium sp. strain and potential medical applications, Ann. Microbiol., 67 (2017) 643-654.

11. M.S., Urbieta, E.R., Donati, K-G., Chan, S., Shahar, L.L., Sin, K.M. Goh, Thermophiles in the genomic era: biodiversity, science, and applications, Biotechnol. Adv., 33 (2015) 633647.

12. R. Rippka, Recognition and identification of cyanobacteria, Method Enzymol., 167 (1988) 28-67.

13. A.R. Rao, A.H. Reddy, S.M. Aradhya, Antibacterial Properties of Spirulina platensis, Haematococcus pluvialis, Botryococcus braunii micro algal extracts, Curr. Trend Biotechnol. Pharm., 4 (2010) 809-819.

14. J. Pradhan, B.K. Das, S. Sahu, N.P. Marhual, A.K. Swain, B.K. Mishra, A.E. Eknath, Traditional antibacterial activity of freshwater microalga Spirulina platensis to aquatic pathogens, Aquac. Res., 43 (2012) 1287-1295. 
15. P.R. Murray, E.J. Baron, M.A. Pfalle, F.C. Tenover, R.H. Yolke, Manual of Clinical Microbiology ( $6^{\text {th }}$ ed.) Washington, DC United States, ASM Press., (1995) 1482 pp.

16. R.J. Porra, W.A. Thompson, P.E. Kreidemann, Determination of accurate extinction coefficients and simultaneous equations for assaying chlorophylls $a$ and $b$ extracted with four different solvents: verification of the concentration of chlorophyll standards by atomic absorption spectroscopy BBA-Bioenergetics, 975 (1989) 84-394.

17. T.C. Hopkins, E.J.S. Graham, J. Schwilling, S. Ingram, S.M Gómez, A.J. Schuler, Effects of salinity and nitrogen source on growth and lipid production for a wild algal polyculture in produced water media, Algal Res., 38 (2019) 101436

18. K.C. Wu, K.C. Ho, C.C. Tang, Y.H. Yau, The Potential of foodwaste leachate as a phycoremediation substrate for microalgal $\mathrm{CO}_{2}$ fixation and biodiesel production, Environ. Sci. Poll. R., (2018). https://doi.org/10.1007/s11356-018 1242-9
19. S.E. Karatay, G. Dönmez, Microbial oil production from thermophile cyanobacteria for biodiesel production, Appl. Energy, 88 (2011) 3632-3635.

20. B. Gris, E. Sforza, T. Morosinotto, A. Bertucco, N. La Rocca, Influence of light and temperature on growth and high-value molecules productivity from Cyanobacterium aponinum, J. Appl. Phycol., 29 (2017) 1781-1790.

21. F. Meng, H., Cui, Y., Wang, X. Li, Responses of a new isolated Cyanobacterium aponinum strain to temperature, $\mathrm{pH}, \mathrm{CO}_{2}$ and light quality, J. Appl. Phycol., 30 (2018) 1525-1532.

22. M.G. de Morais, B. da Silva Vaz., E.G. de Morais, J.A. Costa, Biologically active metabolites synthesized by microalgae, Biomed Res. Int., Article ID 835761 (2015) 1-15.

23. N.H. Noaman, A. Fattah, M. Khaleafa, S.H. Zaky, Factors Affecting antimicrobial activity of Synechococcus leopoliensis, Microbiol. Res., 159 (2004) 395-402. 